Jurnal Sistem Informasi (Journal of Information Systems). 1/13 (2017), 49-66

DOI: http://dx.doi.org/10.21609/jsi.v13i1.528

\title{
PENGEMBANGAN BLUEPRINT IT DENGAN ZACHMAN FRAMEWORK DI STP TRISAKTI
}

\author{
Bambang Widodo ${ }^{1}$ dan Suharjito ${ }^{2}$ \\ ${ }^{1}$ Program Studi Perhotelan, STP Sahid, Jl. Gandaria Raya II Taman Puring, Jakarta, 12130, Indonesia \\ ${ }^{2}$ Magister Teknik Informatika, Universitas Bina Nusantara, Jl. Kebun Jeruk Raya No.27 Jakarta 11530, \\ Indonesia
}

E-mail: bam.widodo@gmail.com,suharjito@yahoo.com

\begin{abstract}
The goals of the article were to create a model enterprise architecture strategic planning of IS/IT college in the form of IT blueprint with Zachman framework in STP Trisakti. Data were compiled by the main supporting documentation college events, questionnaires, interviews and field observations. Development of IT blueprint is done by utilizing the methodology of Ward \& Peppard framework and EA (Enterprise architecture) Zachman Framework is mapped into the Framework as the ultimate form of IT blueprint. Data were analyzed using analysis tools for internal and external environment. Internal environmental analysis using Value Chain, CSF (Critical Success Factor), the current application portfolio and Asset/IT, while the external environment analysis using the PEST (Political, Economic, Social, Technological), Porter's five force and the latest technology trends. It also carried defining enterprise architecture in the form of business architecture, data architecture, application architecture and technology architecture. Results of the analysis were a blueprint IT shaped matrix cell 36 Zachman. It can be concluded that there are 5 stages of implementation in the IT blueprint STP Trisakti with three major central system development in four areas of development of the IS/IT is the application portfolio, HR IT, Perangkat keras, Perangkat lunak and Networking.
\end{abstract}

Keywords: IT Blueprint, Strategic Planning, Ward \& Peppart Framework, Enterprise architecture, Zachman framework

\begin{abstract}
Abstrak
Blueprint IT merupakan arsitektur enterprise yang berbentuk dokumen tata kelola organisasi dalam rentang waktu tertentu, dimana didalamnya berisi pedoman kebutuhan sistem informasi dan perencanaan strategis organisasi dalam mengimplementasikan dan membangun sistem informasi. Sekolah Tinggi Pariwisata (STP) Trisakti merupakan perguruan tinggi yang memandang bahwa pembuatan blueprint IT merupakan suatu langkah dasar yang sangat dibutuhkan untuk mewujudkan visi dan misi serta tujuan perguruan tinggi dalam pengembangan dan implementasi SI/TI yang baik dan terarah. Penelitian ini bertujuan untuk membuat arsitektur enterprise perencanaan strategis SI/TI perguruan tinggi dalam bentuk blueprint IT dengan Zachman Framework di STP Trisakti. Pengembangan blue-print IT tersebut dilakukan dengan memanfaatkan metodologi Ward \& Peppard framework dan EA (Enterprise architecture) Framework yang dipetakan kedalam Zachman Framework sebagai bentuk akhir blueprint IT. Metode analisis yang dilakukan yaitu dengan melakukan analisis lingkungan inter-nal dan eksternal. Analisis lingkungan internal menggunakan Value Chain, CSF (Critical Success Factor), Portofolio Aplikasi saat ini dan Aset SI/TI, sedangkan analisis lingkungan eksternal meng-gunakan PEST (Politik, Ekonomi, Sosial, Teknologi), Porter's five force dan trend teknologi terkini. Selain itu juga dilakukan pendefinisian arsitektur enterprise berupa arsitektur bisnis, arsitektur data, arsitektur aplikasi dan arsitektur teknologi. Hasil penelitian berupa blueprint IT yang berbentuk 36 sel matrik Zachman. Kesimpulan yang di dapat terdapat 5 tahapan implementasi blueprint IT di STP Trisakti dengan tiga sentral utama pengembangan sistem dalam empat area pengembangan SI/TI ya-itu Portofolio aplikasi mendatang, SDM IT, Perangkat keras, Perangkat lunak dan Jaringan.
\end{abstract}

Kata Kunci: Blueprint IT; Perencanaan Strategi; Ward \& Peppard Framework; Enterprise architecture; Zachman frame-work

\section{Pendahuluan}

Perguruan tinggi sebagai lembaga yang bergerak dalam jasa pendidikan saat ini sangat bergantung pada teknologi informasi dan komunikasi (TIK).
Teknogi Informasi yang berkembang dengan sangat pesat saat ini semakin berperan dalam pengambilan keputusan oleh individu, perusahaan maupun instansi pemerintah. Dengan dukungan teknologi informasi maka akan membantu mana- 
jerial dalam mengambil keputusan strategis serta membantu memberikan solusi bisnis [1].

Peran teknologi informasi telah menjadi bagian dari strategi organisasi untuk mencapai tujuannya [2]. Dalam dunia perguruan tinggi, TIK yang didalamnya terdapat Sistem dan Teknologi Informasi (SI/TI) telah menjadi bagian penting dan merupakan suatu kebutuhan bagi perguruan tinggi dalam melaksanakan kegiatan operasionalnya. Peran dari SI/TI dalam mewujudkan Tridharma Perguruan Tinggi telah beralih dari yang tadinya hanya sebatas pelengkap menjadi kebutuhan utama yang menentukan keberhasilan perguruan tinggi yaitu mencetak sumberdaya manusia yang berkualitas.

Tata kelola perguruan tinggi yang baik memegang peranan penting untuk mencapai keberhasilan bahkan salah satu point syarat akreditasi institusi adalah adanya dokumen tata kelola perguruan tinggi berupa Blueprint IT. Tata kelola perguruan tinggi saat ini juga mendapat perhatian dari pemerintah, dan saat ini setiap perguruan tinggi saling berlomba menuju Good university governance. Upaya mewujudkan good university governance pada tiap perguruan tinggi di Indonesia menjadi tugas banyak pihak, mulai dari universitas terkait, hingga Kemendikbud [3]. Dukungan teknologi informasi sangat diperlukan dalam rangka mewujudkan good university governance.

Perencanaan SI/TI merupakan suatu hal yang harus dimiliki serta diimplementasikan per-guruan tinggi. Perencanaan SI/TI sangat diperlu-kan dalam menentukan arah kebijakan perguruan tinggi, baik perencanaan strategis bisnis maupun sistem informasi. Perencanaan strategis SI/TI harus selaras dengan strategi bisnis sebuah perguruan tinggi. Dengan didukung oleh SI/TI yang efektif dan efisien maka diharapkan suatu Perguruan Tinggi akan memperoleh nilai tambah yang lebih baik dari sebelumnya. Melalui perencanaan strategi SI/TI yang bersifat dinamis dan fleksibel, sebuah perguruan tinggi dapat melihat secara objektif kondisi-kondisi internal dan eksternal sehingga dapat mengantisipasi perubahan lingkungan bisnis dan mampu bertahan pada persaingan bisnis yang semakin ketat.

Perencanaan strategis SI/TI ini pada akhirnya menjadi cetak biru (blueprint) IT atau biasa juga disebut peta perjalanan (roadmap) dalam rentang waktu tertentu (umumnya dibuat masa 5 tahun, 10 tahun, 15 tahun, hingga 25 tahun). IT Blueprint pada intinya berisi rencana strategis perusahaan dalam mengimplementasikan dan membangun sistem informasi di Perusahaan. Di dalamnya terdapat pedoman kebutuhan sistem informasi seperti apa yang diperlukan perusahaan.

Sekolah Tinggi Pariwisata (STP) Trisakti merupakan salah satu perguruan tinggi yang sudah lama berdiri. Saat ini pemanfaatan dan penggunaan SI/TI di STP Trisakti sudah cukup banyak akan tetapi tata kelola dan perencanaan SI/TI belum terdokumentasi dengan baik. STP Trisakti sudah memiliki dasar roadmap perencanaan dan pengembangan dalam bentuk dokumen rencana strategis lima tahunan, akan tetapi belum ada perencanaan strategis SI/TI dalam bentuk IT Blueprint, sehingga pembuatan IT Blueprint merupakan suatu langkah dasar yang sangat dibutuhkan untuk mewujudkan visi dan misi serta tujuan perguruan tinggi dalam mengembangkan dan mengimplementasikan SI/TI dengan baik dan terarah.

Perencanaan strategis sistem dan teknologi informasi dibuat berdasarkan Ward \& Peppart framework, Arsitektur Enterprise dan Zachman Framework. Hasil atau luaran nantinya adalah berupa model dan kerangka dasar (blueprint) IT bagi perguruan tinggi.

\section{Metode Penelitian}

Dalam penelitian ini, metode yang digunakan mengacu pada framework Ward dan Peppard dan Framework Zachman. Langkah-langkah pembuatan IT Blueprint dengan pendekatan Zachman Framework melalui tiga tahap utama yaitu sebagai berikut (Gambar 1):

\section{Tahap Persiapan penelitian}

Pada tahap awal, penelitian dimulai dengan menentukan latar belakang dan tujuan penelitian serta mendefinisikan ruang lingkup penelitian, ini dilakukan dengan cara melakukan survey ke objek penelitian.

\section{Tahap Memahami Kebutuhan Bisnis Organi-} sasi

Pada tahapan ini penulis akan menggali informasi untuk memahami kebutuhan bisnis organisasi yaitu dengan melakukan studi literatur guna memperdalam pemahaman mengenai perencanaan strategis SI/TI, kemudian melalukan pengumpulan data dengan cara: 1) mempelajari dokumen pendukung utama kegiatan perguruan tinggi yaitu Statuta, Rencana Induk Pengembangan (RIP), Rencana Strategis (Renstra), Borang Akreditasi dan Standard Operasional Procedure (SOP); 2) memberikan kuisioner kepada kepala unit/departemen IT untuk mengetahui lingkup dan kebermanfaatan sistem yang ada; 3) melakukan wawancara dengan memberikan pertanyaan terbuka untuk menggali lebih dalam mengenai penilaian terhadap aplikasi-aplikasi yang sudah ada serta menggali permasalah-permasalahan yang ada; 4) melalukan observasi untuk melihat langsung pro- 


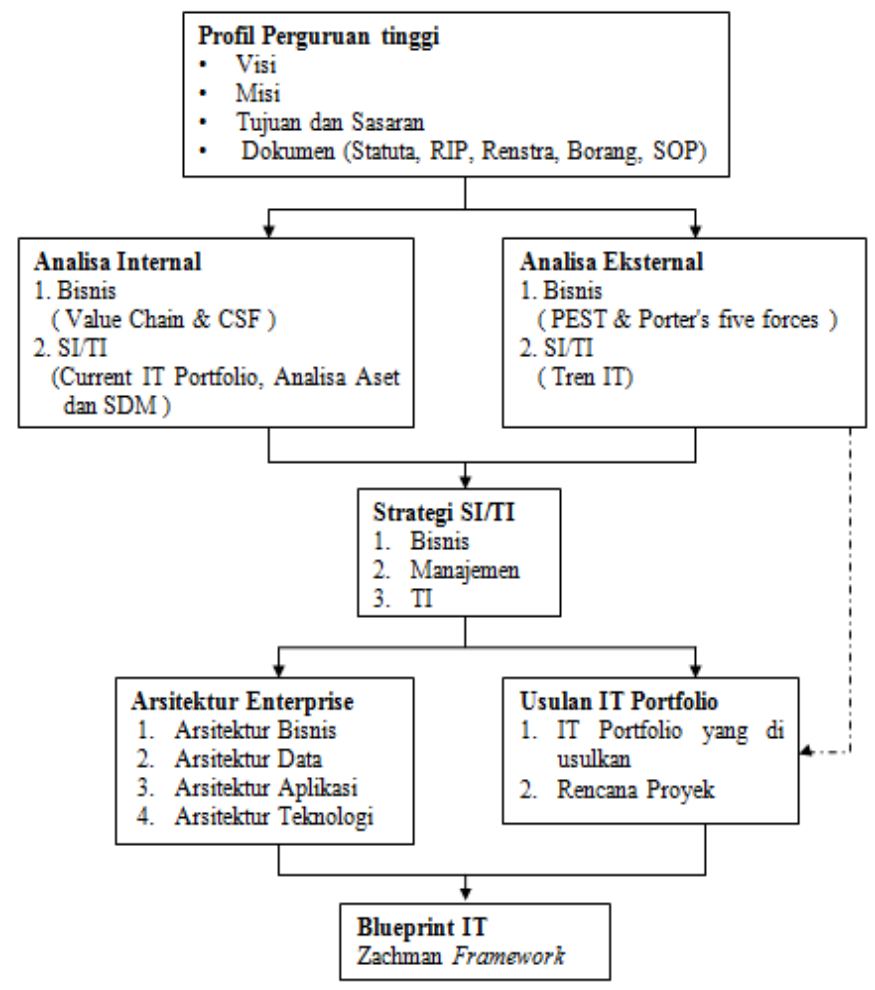

Gambar 1. Tahapan Penelitian

ses yang terjadi dilapangan.

Setelah itu penelitian dilanjutkan dengan menganalisis faktor internal dan eksternal dengan menggunakan teknik analis PEST (Politik, Ekonomi, Sosial dan Teknologi) dan Lima (5) Faktor Persaingan Porter (Porter's Five Forces), CSF, value chain, trend IT, Current IT portofolio, aset dan SDM guna memahami kondisi yang ada saat ini dan menginterpretasikan kebutuhan bisnis yang diperlukan.

\section{Tahap Menentukan Strategi dan Target}

Dengan memanfaatkan hasil analis kebutuhan dari proses sebelumnya maka pada tahap ini solusi SI/TI dapat ditentukan dan dipetakan ke dalam 3 perencanaan strategis SI/TI yaitu bisnis, manajemen dan TI. Solusi Aplikasi-aplikasi yang didapat dipetakan ke dalam empat kuadran pada model portofolio aplikasi McFarlan yaitu strategic, high potential, key operational dan support.

Berdasarkan pemetaan tersebut dibuatlah jadwal perencanaan strategis. Selain itu berdasarkan solusi SI/TI dapat juga ditentukan Arsitektur Enterprise yang terbagi ke dalam empat kategori yaitu bisnis, data, aplikasi dan teknologi. Hasil ekstraksi dari rencana strategis SI/TI, Arsitektur Enterprises dan portofolio aplikasi dikembangkan menjadi blueprint IT dengan Zachman Framework. Blueprint tersebut dijabarkan ke dalam masing-masing barisnya yang terdiri dari scope, business model, system model, technology model, subcontractor, dan function enterprise. Dari masingmasing barisnya diuraikan kolom-kolomnya yang terdiri dari What, How, Where, Who, When, Why.

\section{Pemodelan Sistem Informasi}

Enterprise architecture dengan Zachman Framework merupakan salah satu metodologi pemodelan sistem informasi yang dapat mendefinisikan organisasi secara lengkap. Hasil yang didapat dari proses perencanaan strategi di petakan ke dalam arsitektur zachman menggambarkan kondisi perencanaan strategi perguruan tinggi dengan lebih jelas. Perspektif Planner merupakan bagian dari Strategic Planning, Perspektif Owner merupakan bagian dari Masterplan, sedangkan Perspektif Designer, Builder, Sub Contractor dan Fuctioning Enterprise merupakan bagian dari Blueprint.

Pada kolom-kolom pemodelan perencanaan SI/ TI STP Trisakti (Lampiran Tabel I-VI), terdiri dari: kolom What yang membahas mengenai data yang ada di STP Trisakti, kolom How yang membahas mengenai bagaimana implementasi rencana strategis SI/TI di STP Trisakti, kolom Where yang 
TABEL 1

PROFILE STP TRISAKTI

\begin{tabular}{|c|c|c|}
\hline No & Subjek & keterangan \\
\hline 1 & $\begin{array}{l}\text { Nama } \\
\text { Perguruan } \\
\text { Tinggi }\end{array}$ & Sekolah Tinggi Pariwisata Trisakti \\
\hline 2 & $\begin{array}{l}\text { Tahun } \\
\text { berdiri }\end{array}$ & 1969 \\
\hline 3 & Lokasi & $\begin{array}{l}\text { Jl. IKPN Bintaro No. 1, RT.4 } \\
\text { RW.10, Tanah Kusir, Bintaro, } \\
\text { Pesanggrahan, RT.4/RW.10, } \\
\text { Bintaro, Jakarta Selatan, Kota } \\
\text { Jakarta Selatan, Daerah Khusus } \\
\text { Ibukota Jakarta 12330 }\end{array}$ \\
\hline 4 & Website & http://www.stptrisakti.ac.id \\
\hline 5 & $\begin{array}{l}\text { Program } \\
\text { studi }\end{array}$ & $\begin{array}{l}\text { 1. S2 Pariwisata } \\
\text { 2. S1 Hospitality dan Pariwisata } \\
\text { 3. D4 Perhotelan } \\
\text { 4. D3 Perhotelan } \\
\text { 5. D1 Perhotelan } \\
\text { 6. D4 Usaha Perjalanan Wisata }\end{array}$ \\
\hline 6 & $\begin{array}{l}\text { Jumlah } \\
\text { mahasiswa } \\
\text { aktif }\end{array}$ & Lebih dari 2.400 Mahasiswa \\
\hline & $\begin{array}{l}\text { Jumlah } \\
\text { Lulusan }\end{array}$ & Lebih dari 12.000 Alumni \\
\hline 8 & $\begin{array}{l}\text { Jumlah } \\
\text { Dosen tetap }\end{array}$ & $\begin{array}{l}\text { 1. } 11 \text { Orang lulusan } S 3 \\
\text { 2. } 54 \text { Orang lulusan } S 2\end{array}$ \\
\hline 9 & $\begin{array}{l}\text { Jumlah } \\
\text { Karyawan }\end{array}$ & 60 Orang \\
\hline
\end{tabular}

membahas mengenai lokasi bisnis utama dari STP Trisakti, kolom Who yang membahas mengenai sumber daya manusia yang berperan penting dalam implementasi rencana strategis SI/TI di STP Trisakti, kolom When yang membahas menge-nai Kegiatan-kegiatan dan alokasi penggunaan waktu yang dilakukan dalam pengimplementasian rencana strategis SI/TI di STP Trisakti, dan kolom Why yang membahas mengenai hal-hal yang ingin dicapai oleh STP Trisakti.

Adapun baris-baris pemodelan perencanaan SI/ TI STP Trisakti, terdiri dari:

Baris Planner/Contextual (Scope): merupakan cara pandang Executive Management mengenai Strategic Planning STP Trisakti yang menjelaskan tentang Rencana pengembangan SI/TI.

Baris Owner/Conceptual (Business Model): merupakan cara pandang Senior Operating Management mengenai Masterplan STP Trisakti yang menjelaskan tentang Rencana pengembangan SI/ TI.

Baris Designer/Logical (System Model): merupakan cara pandang Business System Architect mengenai Blueprint IT STP Trisakti yang menjelaskan tentang Rencana pengembangan SI/TI.

Baris Builder/Physical (Technology Model): merupakan cara pandang Information System Architect mengenai Blueprint IT STP Trisakti yang menjelaskan tentang Rencana pengembangan SI/ TI.

Baris Detailed Representation (Sub-Contractor): merupakan cara pandang System Analyst dan programmer mengenai Blueprint IT STP Trisakti yang menjelaskan tentang Rencana pengembangan SI/TI.

Baris Functioning Enterprise: merupakan cara pandang pengguna interface dan provider mengenai Blueprint IT STP Trisakti yang menjelaskan tentang Rencana pengembangan SI/TI.

\section{Hasil dan Pembahasan}

Pembahasan Blueprint IT STP Trisakti difokuskan melalui enam sudut pandang perspektif seperti yang digambarkan pada Gambar 2.

\section{Profil STP Trisakti}

Tabel 1 menunjukkan profil dari STP Trisakti, sebagai latar belakang penelitian dan perencanaan pengembangan blueprint STP Trisakti ini.

\section{Strategi Bisnis Sistem Informasi}

Strategi bisnis sistem informasi dapat dijelaskan melalui Tabel 1.

\section{Strategi Manajemen SI/TI}

Berdasarkan analisis yang telah dilakukan terhadap lingkungan internal dan eksternal SI/TI, diperoleh kondisi-kondisi manajemen bersama dengan Strategi manajemen SI/TI yang diajukan.

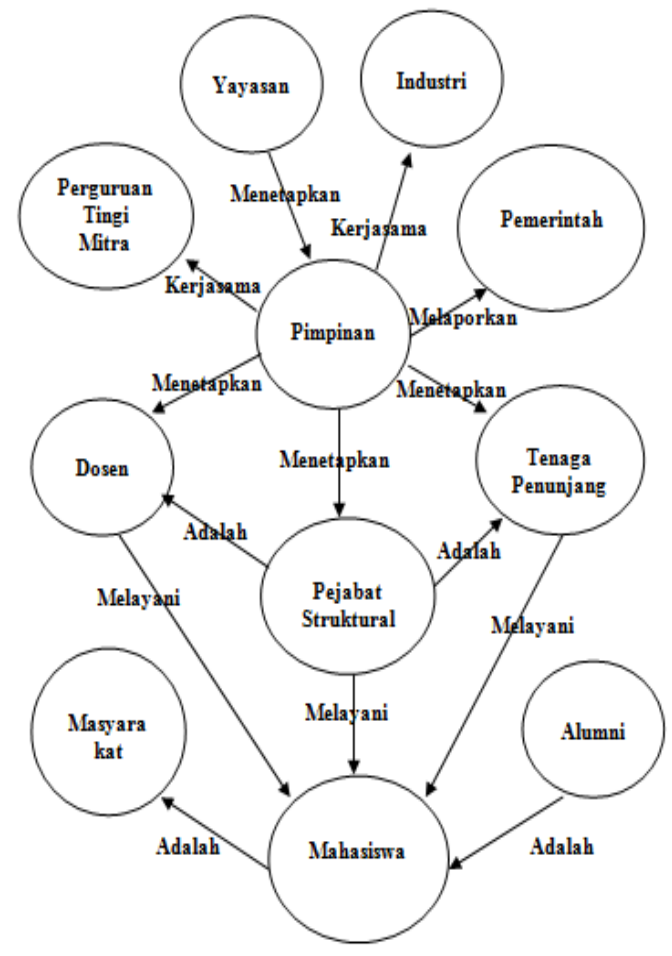

Gambar 4. Hubungan entitas bisnis 


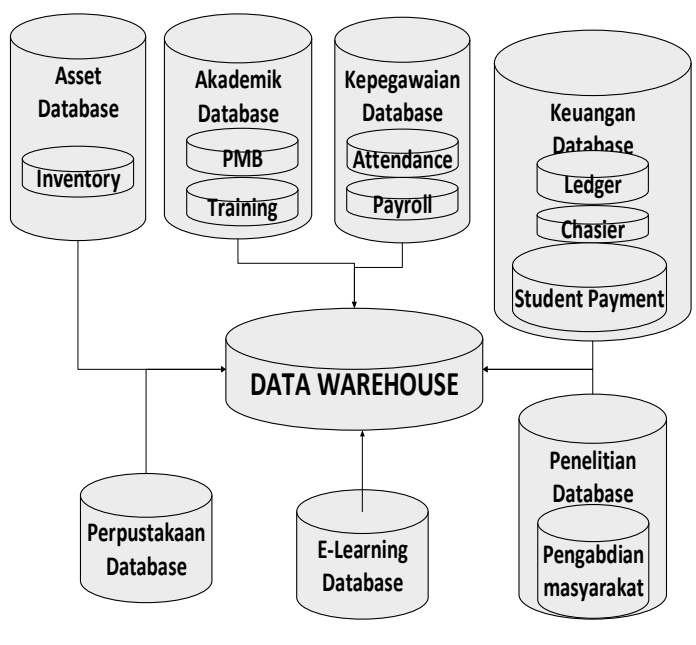

Gambar 5. Relation Data Model STP Trisakti

Kondisi yang pertama adalah posisi Divisi IT dalam struktur organisasi terletak pada unit UPT Datin di bawah Wakil Ketua I dengan level organisasi IIIA yang berarti UPT Datin adalah level manajer terrendah dalam struktur organisasi sehingga wewenang dan tanggung jawab dalam mempengaruhi organisasi sangat rendah sedangkan dari hasil analisis semua aplikasi yang dikelola UPT Datin digunakan oleh hampir seluruh unit yang ada di perguruan tinggi.

Kondisi yang kedua adalah bahwa dengan adanya sistem Vicon Polycom sebagai fasilitas SI Pembelajaran online melalui kelas virtual, maka diperlukan pengaturan khusus terhadap alokasi bandwidth internet. Namun, tidak ada SDM IT khusus untuk menangani jaringan dan internet.

Kondisi yang ketiga adalah bahwa SI Pembelajaran e-Learning akan digunakan pada seluruh prodi yang ada di perguruan tinggi. Akan tetapi belum ada unit atau SDM IT yang khusus menangani e-Learning.

Kondisi yang keempat adalah bahwa jumlah peralatan perangkat keras yang harus ditangani sangat banyak sedangkan hanya terdapat satu orang teknisi. Begitu juga dengan kondisi kelima yaitu bahwa kebutuhan akan sistem informasi dari hasil analisis internal dan eksternal menghasilkan lebih dari 20 aplikasi yang dapat dikembangkan. Akan tetapi, belum ada pula SDM IT yang khusus menangani analisa sistem.

Untuk itu, Strategi manajemen SI/TI yang dapat diusulkan untuk setiap kondisi tersebut di antaranya adalah sebagai berikut:

Untuk kondisi pertama, strategi manajemen SI/TI yang dapat dilakukan adalah dengan mengubah peran divisi IT menjadi kunci keberhasilan organisasi. Hal ini dapat dilakukan dengan menempatkan UPT Datin di bawah Ketua Perguruan tinggi langsung dengan level IC sehingga peran

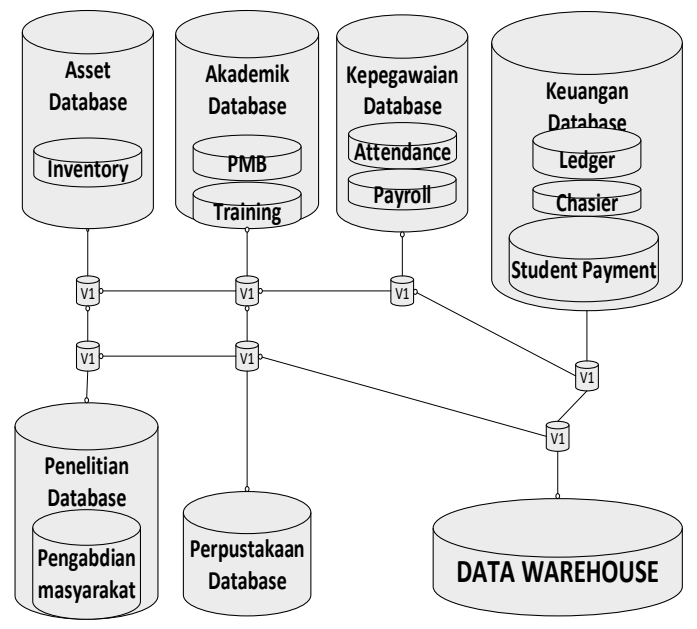

Gambar 6. Physical Data Model

dan fungsi UPT Datin bisa mempengaruhi perkembangan organisasi secara langsung. Selain itu dapat pulang diusulkan mengenai pembentukan struktur baru di bawah UPT Datin yang khusus untuk menangani e-Learning. Dengan demikian strategi ini dapat diaplikasikan untuk membantu memecahkan permasalahan pada kondisi ketiga.

Untuk permasalahan pada kondisi-kondisi lain dapat dilakukan penambahan jumlah staff yang khusus menangani jaringan, e-learning, peralatan perangkat keras, serta sebagai analis sistem. Sementara itu, usulan struktur organisasi yang baru adalah dengan menempatkan UPT Pusdatin di level IC dan penambahan 3 bidang kerja yaitu bidang E-Learning dan Jaringan \& Internet dan analis sistem, berikut struktur organisasi yang diusulkan. Dari usulan strategi manajemen SI/TI tersebut dapat dibuat usulan kebutuhan sumber daya Manusia di unit Pusdatin adalah sebagaimana ditunjukkan pada Gambar 3.

\section{Strategi Teknologi Informasi}

Dari segi teknologi informasi sendiri, pada STP Trisakti diperoleh kondisi-kondisi TI sebagai berikut:

Kondisi pertama adalah bahwa hampir $90 \%$ perangkat lunak yang dipakai menggunakan produk Microsoft, sehingga keberlanjutan campus agreement untuk lisensi penggunaan perangkat lunak dengan Microsoft harus dijamin.

Dari segi perangkat keras, terdapat bebera-pa perangkat keras sudah digunakan lebih dari 5 tahun. Untuk itu perlu adanya peremajaan perangkat keras minimal per 3 tahun sekali.

Dari segi jaringan, diperlukan juga pengadaan kabel LAN dengan kualitas yang lebih baik dengan kecepatan optimal hingga $1000 \mathrm{mb}$ dan upgrade router ke $1000 \mathrm{mb}$, serta penyederhanaan akses 


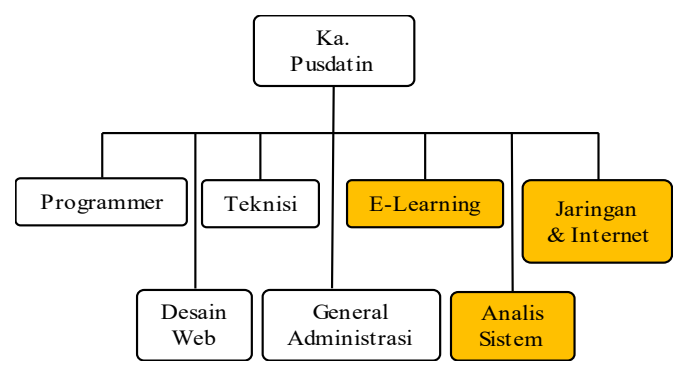

Gambar 3. Usulan struktur organisasi unit Pusdatin

node pada tiap gedung dan lantai agar kecepatan optimal. Pengadaan perangkat keras yang dapat menunjang teknologi mobile disertai dengan penambahan bandwith internet juga dibutuhkan guna mengantisipasi pertambahan penggunaan peralatan mobile. Penambahan bandwidth menjadi lebih krusial karena kelas virtual yang menggunakan aplikasi Vicon Polycom sangat tergantung pada jalur bandwith yang tersedia.

Sebagai tambahan, perlu diperhatikan penggunaan peralatan IT yang menjamin ramah lingkungan, penempatan sumber daya dengan metode cloud guna mengefektifkan biaya dan sumber daya IT, pengadopsian teknik pengembangan perangkat lunak yang mendukung konsep Agile Programming, serta pengembangan sistem keamanan yang menjamin bahwa data dan informasi terjaga kerahasiaannya sesuai dengan hak akses penggu-na juga diperlukan.

Berdasarkan paparan kondisi teknologi informasi di STP Trisakti maka strategi TI yang dapat diajukan di antaranya adalah 1) dilakukan pembelian lisensi dengan Microsoft melalui campus agreement secara berkala dan berlanjut; 2) dibuat anggaran untuk peremajaan perangkat keras minimal per 3 tahun sekali; 3) membuat standar pengelolaan LAN yang dapat mengantisipasi kebutuhan kedepan dan melakukan pembelian perangkat yang dibutuhkan; 4) membuat topologi LAN yang dapat mengantisipasi kebutuhan kedepan; 5) penambahan bandwith minimal 25\% dari kecepatan terakhir per tahun; 6) dibuat manajemen pengaturan alokasi bandwith internet khusus untuk penggunaan kelas virtual; 7) membeli perangkat keras yang mendukung teknologi mobile; 8) membeli peralatan IT yang sudah memiliki sertifikasi ramah lingkungan; 9) memiliki fasilitas layanan cloud; 10) membangun teknik pengembangan perangkat lunak yang mendukung konsep Agile Program-ming; serta 11) membuat standar keamanan IT

\section{Batasan dan Aturan Implementasi SI/TI}

Dalam implementasi SI/TI terdapat batasan-batasan atau aturan yang harus diterapkan. Batasan- batasan tersebut di antaranya adalah: 1) hak akses untuk masing-masing pengguna ditentukan sesuai dengan lingkup unit/departemen dan tugas tanggung jawabnya; 2) perangkat lunak yang digunakan dapat menggunakan perangkat lunak free open source maupun yang berbayar; 3) perangkat lunak basis data menggunakan perangkat lunak berbayar demi jaminan keamanan dan pengembangan di masa depan; 4) aplikasi yang dibuat untuk konsumsi public harus dapat dijalankan di perangkat mobile dan web; serta 5) peralatan IT harus memiliki sertifikasi ramah linkungan dan mendukung teknologi mobile.

Sementara aturan-aturan yang digunakan dalam implementasi SI/TI di antaranya adalah sebagai berikut: 1) perangkat lunak basis data menggunakan Microsoft SQL Server 2008 R2; 2) bahasa pemrograman yang digunakan adalah PowerBuilder, PHP, HTML; 3) Framework PHP yang digunakan adalah Code Igniter; 4) aplikasi Web server yang digunakan Apache; 5) aplikasi dapat dijalankan dijaringan lokal dan internet; 6) sangat disarankan pembuatan aplikasi menggunakan metode agile programming; dan 7) untuk aplikasi yang menggunakan template dibuatkan service untuk mensinkronkan aplikasi dengan basis data internal.

\section{Akses Pengguna Terhadap Layanan SI/TI}

Konfigurasi hak akses pengguna terdiri dari: 1) View: akses untuk melihat data; 2) New: akses untuk menambah data; 3) Save: akses untuk menyimpan data; 4) Edit: akses untuk mengedit data; 5) Delete: akses untuk menghapus data; dan 6) Print: akses untuk mencetak data.

Masing-masing pengguna dalam menggunakan aplikasi sistem informasi dibagi menjadi 2 jenis yaitu pengguna authorize dan group authorize. Pengguna authorize dapat mengakses daftar menu yang boleh diakses berdasarkan pengguna individu. sedangakan group authorize dapat mengakses daftar menu yang boleh diakses berdasarkan grup atau departemen. Setiap aktifitas login pengguna dicatat oleh sistem dengan format tanggal;jam;menit, IP address host, dan MAC addressnya. Selain itu, pengguna juga dibatasi aksesnya untuk membuka prodi tertentu saja.

Untuk menjaga pelayanan yang tepat bagi masing-masing role tersebut, dalam proses pengkodean akses pengguna, terdapat beberapa hal yang perlu diperhatikan, yaitu: 1) sistem login pengguna harus dipastikan aman dan telah dilakukan uji test keamanan sistem; 2) pengguna yang telah diberi otoritas bertanggung jawab penuh terhadap sistem, dicatat secara otomatis log kegiatan selama penggunaan sistem; 3 ) sistem otomatis meminta pengguna untuk mengganti password dalam 


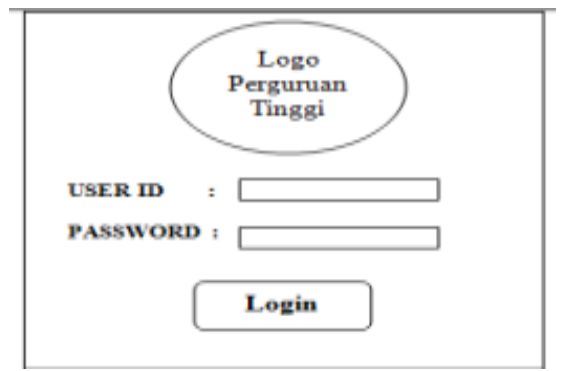

Gambar 7. Rancangan layar Login

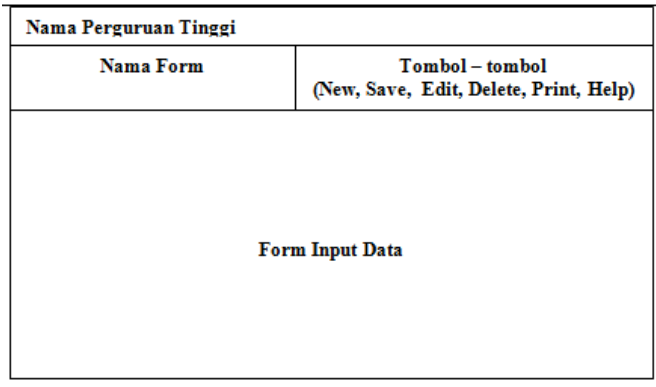

Gambar 9. Rancangan Layar Input

waktu periode tertentu dengan standar password yang baik; 4) sistem dibuat auto-log-off apabila terjadi proses idle pada penggunaan sistem; 5) disable beberapa fungsi yang mengancam keamanan sistem; serta 6) untuk tabel tertentu ditambah kolom validasi pengguna yang berfungsi untuk mencatat perubahan record oleh pengguna yang bertanggungjawab berupa kode pengguna, tanggal jam, dan menit perubahan.

\section{Arsitektur Sistem Informasi}

Arsitektur Bisnis

Arsitektur bisnis dilihat dari entitas yang ada di dalamnya beserta hubungan antarentitas digambarkan pada Gambar 4.

\section{Arsitektur Data}

Sebagaimana yang ditunjukkan pada Gambar 5 dan 6 , beberapa basis data yang terlibat beserta dengan fungsinya dijelaskan sebagai berikut: 1) Basis data Akademik: digunakan untuk menampung data kegiatan penerimaan mahasiswa baru, proses akademik, training; Basis data Keuangan: digunakan untuk menampung data pembayaran mahasiswa, kasir, general ledger; 2) Basis data Kepegawaian: digunakan untuk menampung data kehadiran pegawai dan payroll; 3) Basis data Asset: digunakan untuk menampung data inventory; 4) Basis data Penelitian: digunakan untuk menampung data proses penelitian dan proses pengabdian masyarakat; 5) Basis data Perpustakaan: digunakan untuk me-

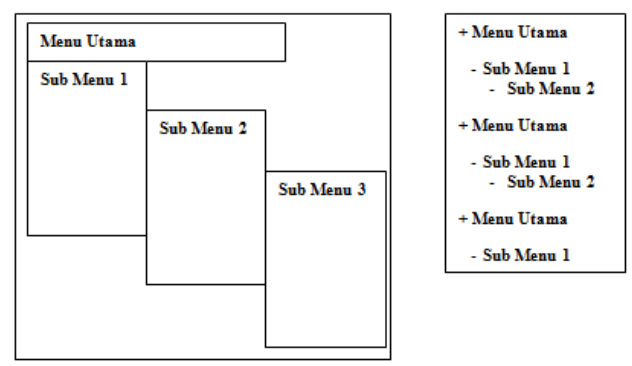

Gambar 8. Rancangan Layar Menu

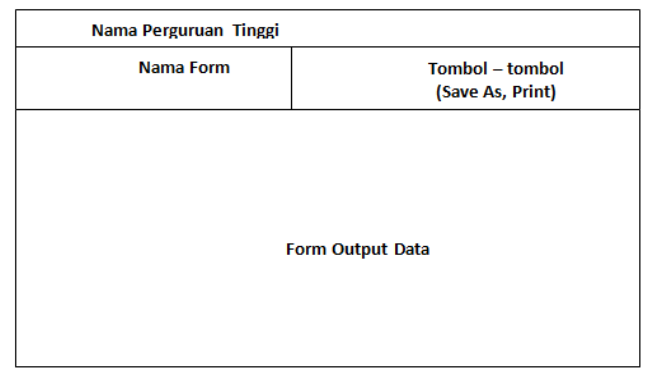

Gambar 10. Rancangan Layar Output

nampung data pengelolaan perpustakaan; 6) Data warehouse: digunakan sebagai data analisis yang merupakan ekstraksi dari semua basis data yang akan digunakan untuk kepentingan khusus.

Aturan proses datanya adalah sebagai berikut: 1) data-data yang telah diverifikasi dan validasi diisikan kedalam tabel-tabel yang telah dibuat didalam basis data melalui aplikasi yang telah disediakan; 2) sumber data diperoleh melalui formulir, dokumen, bukti transaksi baik hardcopy maupun softcopy; 3) data dapat diinput ke sistem dan diatur sesuai dengan hak akses pengguna.

\section{Arsitektur Aplikasi}

Arsitektur Sistem Aplikasi

Arsitektur dari sistem aplikasi ini dibagi menjadi dua bagian yaitu: aplikasi client-server dan aplikasi 3-tier (Gambar 12 dan 13).

\section{Rancangan Antarmuka Aplikasi}

Rancangan antarmuka aplikasi yang akan dikembangkan sebagai berikut: 1) warna dasar sistem adalah kuning oranye; 2) nama perguruan tinggi ditampilkan di layar utama dan taskbar aplikasi; 3) logo perguruan tinggi ditampilkan di layar utama dan pada setiap hasil cetak laporan nama pengguna yang sedang login menggunakan aplikasi ditampilkan di layar; 4) tombol New, Save, Edit, Delete dan Print ditampilkan sesuai dengan otoritas hak akses pengguna dan sesuai dengan kebutuhan form aplikasi. 


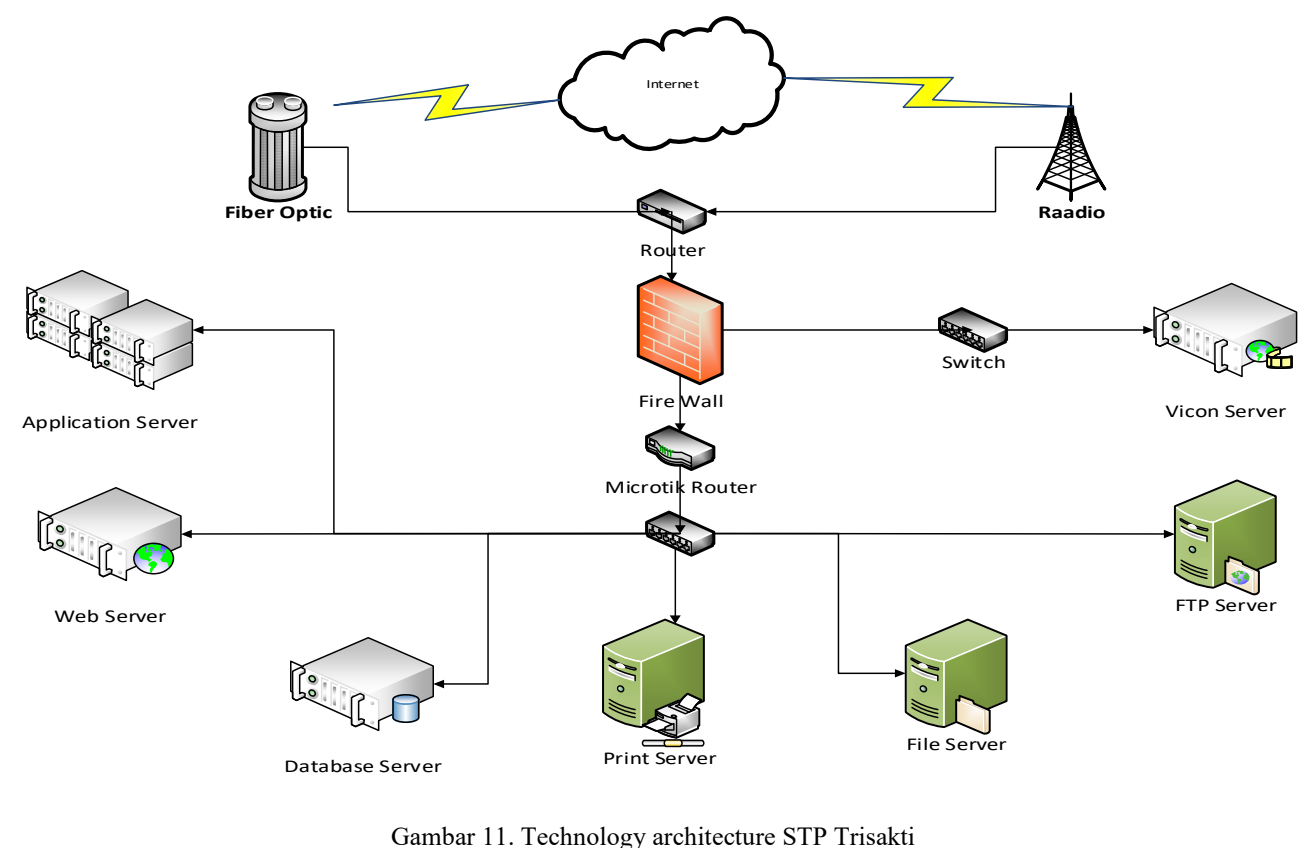

Rancangan layar sistem yang dikembangkan secara garis besar dapat digambarkan seperti pada Gambar 7-10 untuk halaman Login, Menu, Form Input, dan Form Output berturut-turut.

\section{Arsitektur Teknologi}

Secara umum, arsitektur teknologi di STP Trisakti digambarkan pada Gambar 11.

\section{Konfigurasi Jaringan}

Diperlukan konfigurasi seluruh jaringan sedemikian hingga seluruh jaringan tersebut dapat terhubung dengan server dimana sistem informasi akan dipasang. Konfirgurasi ini ditentukan sebagai berikut: 1) koneksi internet utama menggunakan jalur fiber optic jika ada gangguan disediakan backup jalur melalui wireless; 2) IP public digunakan untuk server tertentu (web server, ftp server, application server, vicon server); 3) IP static digunakan untuk komputer server dan komputer lokal; 4) IP Dinamic digunakan untuk perangkat yang terhubung melalui wireless point access (hotspot); 5) Mikrotik dipasang sebagai pengatur lalu lintas data dijaringan dan juga berfungsi sebagai firewall; 6) Penyimpanan email menggunakan cloud application (Google Apps); dan 7) Protokol komunikasi menggunakan TCP/IPv4.

\section{Usulan Portofolio Aplikasi dan Penjadwalan}

Rentang waktu yang digunakan dalam proses ini adalah 5 tahun dimulai dari bulan januari 2017 sampai dengan bulan desember 2021 .
Detail kegiatan per tahun sebagai berikut: kegiatan pada tahun pertama adalah menyelesaikan pengembangan aplikasi yang sudah ada sebelumnya dan perekrutan SDM IT yang dibutuhkan dalam pembuatan aplikasi yang baru beserta infrastrukturnya. Di tahun kedua, dilakukan pembuatan aplikasi yang diusulkan dengan fokus utama aplikasi strategis dan key operation. Di tahun ketiga, dilakukan pembuatan aplikasi yang diusulkan dengan fokus utama aplikasi key operation dan high potential. Pada tahun keempat, kegiatan yang dilakukan adalah membuat aplikasi yang diusulkan dengan fokus utama aplikasi key operation. Terakhir, di tahun kelima, dilakukan pembuatan aplikasi yand diusulkan dengan fokus utama aplikasi support.

\section{Aturan Waktu Pembuatan Sistem dan Proses Data}

Dalam pembuatan sistem ini, terdapat aturan waktu yang perlu dipatuhi, yaitu waktu pembuatan basis data untuk masing-masing aplikasi maksimal dua minggu sedangkan waktu pembuatan desain antarmuka aplikasi untuk masing-masing aplikasi maksimal adalah tiga minggu. Waktu pembuatan kode program untuk masing-masing aplikasi maksimal delapan adalah minggu, waktu untuk testing dan uji keamanan sistem maksimal satu minggu, serta waktu untuk membuat dokumentasi dan pelatihan maksimal adalah satu minggu.

Adapun untuk proses data, juga terdapat aturan-aturan tertentu, yaitu bahwa data-data yang telah diverifikasi dan validasi harus diisikan ke 
dalam tabel-tabel yang telah dibuat di dalam basis data melalui aplikasi yang telah disediakan. Data harus dapat diperoleh melalui formulir, dokumen, bukti transaksi baik hardcopy maupun softcopy. Data juga harus dapat diinput ke sistem diatur sesuai dengan hak akses pengguna.

\section{Kesimpulan}

Berdasarkan hasil analisis atas kondisi Sekolah Tinggi Pariwisata Trisakti (STP Trisakti) saat ini dalam pembuatan blueprint IT serta perumusan strategi sistem informasi untuk mendukung efektivitas dan meningkatkan efisiensi proses bisnis STP Trisakti, maka dapat disimpulkan sebagai berikut:

Blueprint IT yang dihasilkan sesuai dengan kebutuhan STP Trisakti dalam perencanaan strategis 5 tahun ke depan. Manajemen STP Trisakti dapat mengetahui faktor-faktor yang penting yang diperlukan dalam mengembangkan suatu sistem informasi dengan panduan blueprint IT STP Trisakti yang telah dibuat. Faktor-faktor tersebut dapat dilihat dari setiap perspektif dan abstraksi yang terdapat pada sel-sel zachman yang dihasilkan.

Terdapat tiga sentral utama pengembangan sistem yaitu SI Akademik, SI Keuangan modul Ledger dan Data warehouse dengan dua arsitektur aplikasi yang dikembangkan yaitu 2 tier (client-server) dan 3 tier (web base).

Kondisi topologi jaringan saat ini sudah baik hanya perlu peningkatan kecepatan dengan mengupgrade kwalitas kabel dan hub hingga kecepatan bisa mencapai 1000 mbps dan secara bertahap kecepatan koneksi internet ditingkatkan.

Strategi pengembangan blueprint IT dibagi menjadi 5 tahapan yaitu tahun pertama menyelesaikan pengembangan aplikasi yang sudah ada sebelumnya dan perekrutan SDM IT yang dibutuhkan dalam pembuatan aplikasi yang baru beserta infrastrukturnya, sedangkan untuk tahun kedua sampai kelima melakukan pembuatan aplikasi yang diusulkan dengan fokus utama aplikasi yang ber-sifat strategis dan key operation pada tahun kedua, tahun ketiga key operation dan high potential, tahun keempat key operation, dan tahun kelima support.

Perencanaan Pengembangan SI/TI STP Trisakti terdapat empat area yaitu portofolio aplikasi mendatang, SDM IT, perangkat ke-ras dan perangkat lunak serta jaringan.

Restrukturisasi organisasi divisi IT diperlukan untuk merubah peran divisi IT yang sebelumnya hanya sebagai support menjadi salah satu kunci keberhasilan organisasi.

Dalam rangka pencapaian efektivitas dan efisiensi proses bisnis STP Trisakti dan penelitian selanjutnya maka penulis memberikan beberapa saran, yaitu bahwa dalam melakukan implemen- tasi blueprint IT sebaiknya STP Trisakti mempersiapkan infrastruktur organisasi terlebih dahulu seperti misalnya menyiapkan kebijakan pengelolaan operasional SI/TI, sumber daya manusia yang akan menangani SI/TI serta SOP IT dalam proses pelaksanaannya sehingga dalam penerapannya tidak terhambat dengan peraturan dan sumber daya. Selain itu, dalam penelitian selanjutnya sebaiknya dilakukan pengujian dari blueprint IT yang dihasilkan dan dibuatkan roadmap implementasi bluepri$n t$ IT untuk memperjelas tahapan implementasi serta manajemen resiko maupun pengelolaan resikonya.

\section{Referensi}

[1] Rosmalina, "Model Rencana Strategis Sistem Informasi di Universitas Bale Bandung (UNIBBA)," Jakarta, 2014.

[2] Margareta Dyah Retno Hapsari Husadini, Paulus Insap Santosa, and Eko Nugroho, "Model Perencanaan Strategis Sistem Informasi Rumah Sakit Wisma Rini Kabupaten Pringsewu," in Seminar Nasional Ilmu Komputer, Semarang, 2015.

[3] Kuswardani Mutyarini and Jaka Sembiring, "Arsitektur Sistem Informasi untuk Institusi Perguruan Tinggi di Indonesia," in Konferensi Nasional Teknologi Informasi \& Komunikasi untuk Indonesia, Bandung, 2006.

[4] Margaret Puspitarini. (2012, January) OkeZone News. [Online]. http://news.okezone. com/read/2012/01/09/373/553998/mendikbu d-canangkan-good-university-governance

[5] Andika Agus Slameto, Ema Utami, and Abas Ali Pangera, "Penerapan Zachman Framework dalam Merancang Sistem Pelaporan Kerusakan Komputer," in Seminar Nasional Teknologi Informasi dan Multimedia, Yogyakarta, 2013.

[6] Krisdanto Surendro, Implementasi Tata Kelola Teknologi Informasi. Bandung: Informatika, 2009.

[7] John ward and joe peppard, Strategic Planning for Information System third edition. England: John Wiley \& Sons, 2002.

[8] Aris Puji Widodo, "Enterprise architecture Model untuk Aplikasi Goverment," Jurnal Masyarakat Informatika, pp. Volume 1, Nomor 1, 2012.

[9] Roni Yunis and krisdanto Suhendro, "Implementasi Enterprise architecture Perguruan Tinggi," in Seminar Nasional Aplikasi Teknologi Informasi, Yogyakarta, 2010.

[10] John A Zachman, "John Zachman's Concise Definition of The Enterprise Framework," Zachman International, 2008. 
[11] John Ward and Joe Peppard, Strategic Planning For Information System. 3rd Edition.: John Willey \& Sons, Buffins Lane, Chichester, 2002.

[12] Rainer, Potter Turban, Introduction To Information Technology. Second Edition. New Jersey: John Willey \& Sons, 2003.

[13] Michael Eugene Porter, Competitive Strategy. New York: The Free Press A Division of Macmillan, Inc., 1998.

[14] Warren F McFarlan, "Portfolio approach to information systems," 1981.

[15] G Osvalds, Definition od Enterprise Architecture-Centric Models for The Systems Engineers.: TASC Inc., 2001.

[16] H S Kourdi, "Framework for Enterprise architecture," IEEE, September, 2007.
[17] C Laudon Kenneth and Price Loudon Jane, Management Information Systems Managing the Digital Firm, 12th Edition.: Prentice Hall, 2012.

[18] Lawrence R Jauch and William F Glueck, Manajemen Dan Strategis Kebijakan Perusahaan. Jakarta: Erlangga, 1989.

[19] B Hariadi, Strategi manajemen: Strategi Memenangkan Perang Bisnis. Jawa Timur: Bayumedia Publishing, 2005.

[20] H M Jogiyanto, Analisis dan Desain Sistem Informasi: Pendekatan Terstruktur Teori dan Praktik Aplikasi Bisnis. Yogyakarta: Penerbit Andi, 2005.

[21] "Gartner Newsroom", Gartner.com, 2017. [Online]. Available: http://www.gartner.com /newsroom/. [Accessed: 28-Apr-2017]

\section{Lampiran}

LAMPIRAN TABEL I

PLANNER/CONTECTUAL (SCOPE) BLUEPRINT IT STP TRISAKTI

\begin{tabular}{l}
\hline Perspektif \\
\hline Abstraksi \\
\hline DATA - What - (Things) \\
Arsitektur Bisnis, Daftar Entitas bisnis, Entitas Bisnis STP Trisakti \\
FUNCTION - How - (Process) \\
Arsitektur Bisnis \\
Daftar proses Kinerja bisnis \\
Entitas Bisnis STP Trisakti \\
NETWORK - Where - (Location) \\
Profile STP Trisakti \\
Lokasi STP Trisakti \\
Profile STP Trisakti \\
PEOPLE - Who - (People) \\
Arsitektur Bisnis \\
Daftar jabatan / Institusi yang penting dalam Bisnis \\
Entitas Bisnis STP Trisakti \\
TIME - When - (Time) \\
Usulan Portpolio Aplikasi Mendatang \\
Kategori Portofolio Aplikasi mendatang STP Trisakti \\
Rentang waktu bisnis dan detail kegiatan per tahun \\
MOTIVATION - Why - (Motivation) \\
Profile STP Trisakti \\
Visi dan misi secara umum STP Trisakti.
\end{tabular}

LAMPIRAN II

OWNER/CONCEPTUAL (BUSINESS MODEL) BLUEPRINT IT STP TRISAKTI

\begin{tabular}{ll}
\hline Perspektif & Owner / Conceptual (Business Model) \\
\hline Abstraksi & \\
\hline DATA - What - (Things) \\
Arsitektur Bisnis, Hubungan Entitas Bisnis \\
FUNCTION - How - (Process) \\
Arsitektur Bisnis \\
Proses Bisnis STP Trisakti \\
NETWORK - Where - (Location) \\
Arsitektur Teknologi \\
Topologi Jaringan STP Trisakti \\
PEOPLE - Who - (People) \\
Strategi Manajemen SI/TI \\
Usulan struktur organisasi unit Pusdatin \\
TIME - When - (Time) \\
Jadwal Perencanaan Strategis SI/TI \\
Jadwal rencana kegiatan 5 tahun \\
MOTIVATION - Why - (Motivation) \\
Profile STP Trisakti \\
Tujuan STP Trisakti
\end{tabular}


LAMPIRAN TABEL III

DESIGNER/LOGICAL (SYSTEM MODEL) BLUEPRINT IT STP TRISAKTI

\begin{tabular}{l}
\hline Perspektif \\
\hline Abstraksi \\
\hline DATA - What - (Things) \\
Arsitektur Data, Relation Data Model \\
FUNCTION - How - (Process) \\
Arsitektur Aplikasi, Arsitektur Aplikasi Client-Server, Arsitektur Aplikasi 3-tier \\
NETWORK - Where - (Location) \\
Arsitektur Teknologi \\
Distributed system Architecture STP Trisakti \\
PEOPLE - Who - (People) \\
Arsitektur Aplikasi, Rancangan Antar Muka Sistem, Rancangan Layar \\
Gambar 14. Rancangan layar Login \\
Gambar 15. Rancangan layar Menu \\
Gambar 16. Rancangan layar Input \\
Gambar 17. Rancangan layar Output \\
TIME - When - (Time) \\
Jadwal Perencanaan Strategis \\
Event perencanaan proyek \\
MOTIVATION - Why - (Motivation) \\
Strategi Teknologi Informasi \\
Batasan-batasan atau aturan yang diterapkan dalam implementasi SI/TI \\
\hline
\end{tabular}

LAMPIRAN TABEL IV

Builder/Physical (TECNOLOGY MODEL) BLUEPRINT IT STP TRISAKTI

\begin{tabular}{l}
\hline Perspektif \\
\hline Abstraksi \\
\hline DATA - What - (Things) \\
Arsitektur Data \\
Physical Data Model \\
FUNCTION - How - (Process) \\
Arsitektur Aplikasi \\
System Design \\
NETWORK - Where - (Location) \\
Arsitektur Teknologi \\
Technology architecture STP Trisakti \\
PEOPLE - Who - (People) \\
Arsitektur Aplikasi \\
Presentation Architecture \\
TIME - When - (Time) \\
Jadwal Perencanaan Strategis SI/TI \\
Standar waktu pembuatan aplikasi \\
MOTIVATION - Why - (Motivation) \\
Strategi Teknologi Informasi \\
Aturan - aturan yang digunakan dalam implementasi SI/TI \\
\hline
\end{tabular}

LAMPIRAN TABEL $\mathrm{V}$

DETAILED REPRESENTATION (SUB-CONTRACTOR) BLUEPRINT IT STP TRISAKTI

\begin{tabular}{ll}
\hline Perspektif & Detailed Representation (Sub-Contractor) \\
\hline Abstraksi & \\
\hline DATA - What - (Things) & \\
Arsitektur data & \\
Daftar Database dan penjelasannya & \\
FUNCTION - How - (Process) & \\
Strategi Bisnis Sistem Informasi & Value Chain Strategi bisnis sistem informasi STP Trisakti \\
Hubungan Antar sistem STP Trisakti & \\
NETWORK - Where - (Location) & \\
Arsitektur Teknologi & \\
Konfigurasi seluruh jaringan agar dapat terhubung dengan server dimana sistem informasi akan dipasang. \\
PEOPLE - Who - (People) \\
Strategi Teknologi Informasi \\
Konfigurasi hak akses user \\
Metode penggunaan aplikasi \\
TIME - When - (Time) \\
Jadwal Perencanaan Strategis SI/TI \\
Keterangan maksimal waktu pembuatan sistem \\
MOTIVATION - Why - (Motivation) \\
Strategi teknologi Informasi \\
Aturan proses pengkodean aplikasi
\end{tabular}


LAMPIRAN TABEL VI

FUNCTION ENTERPRISE BLUEPRINT IT STP TRISAKTI

\begin{tabular}{l}
\hline Perspektif \\
\hline Abstraksi \\
\hline DATA- What - (Things) \\
Strategi Teknologi informasi \\
Aturan proses data \\
FUNCTION - How - (Process) \\
Arsitektur Aplikasi \\
Form Login \\
Form Input dan Menu \\
Form Output \\
NETWORK - Where - (Location) \\
Strategi Teknologi informasi \\
Kebutuhan Infrastruktur pendukung jaringan \\
PEOPLE - Who - (People) \\
Strategi Teknologi Informasi \\
Pembagian hak akses penggunaan sistem \\
TIME - When - (Time) \\
Jadwal Perencanaan Strategis SI/TI \\
Jadwal Perencanaan Pengembangan SI/TI STP Trisakti \\
MOTIVATION - Why - (Motivation) \\
Standard Operational Procedure ( SOP) dalam menggunakan aplikasi sistem informasi \\
\hline
\end{tabular}

\begin{tabular}{lll}
\multicolumn{3}{c}{ LAMPIRAN TABEL VII } \\
\multicolumn{1}{c}{ USULAN SDM STP TRISAKTI } \\
\hline No & Jenis SDM & Jumlah \\
\hline 1 & Analis sistem & 1 \\
2 & Jaringan dan Internet & 1 \\
3 & E-Learning & 1 \\
4 & Teknisi & 1 \\
\hline
\end{tabular}

\begin{tabular}{llll}
\multicolumn{4}{c}{ LAMPIRAN TABEL IX } \\
\multicolumn{4}{c}{ KEBUTUHAN INFRASTRUKTUR PENDUKUNG } \\
\hline No & Nama Peralatan & unit & Jumlah \\
\hline 1 & Kabel UTP Cat 6e & box & 5 \\
2 & RJ45 Cat 6 & box & 2 \\
3 & Switch Gigabit & buah & 10 \\
\hline
\end{tabular}

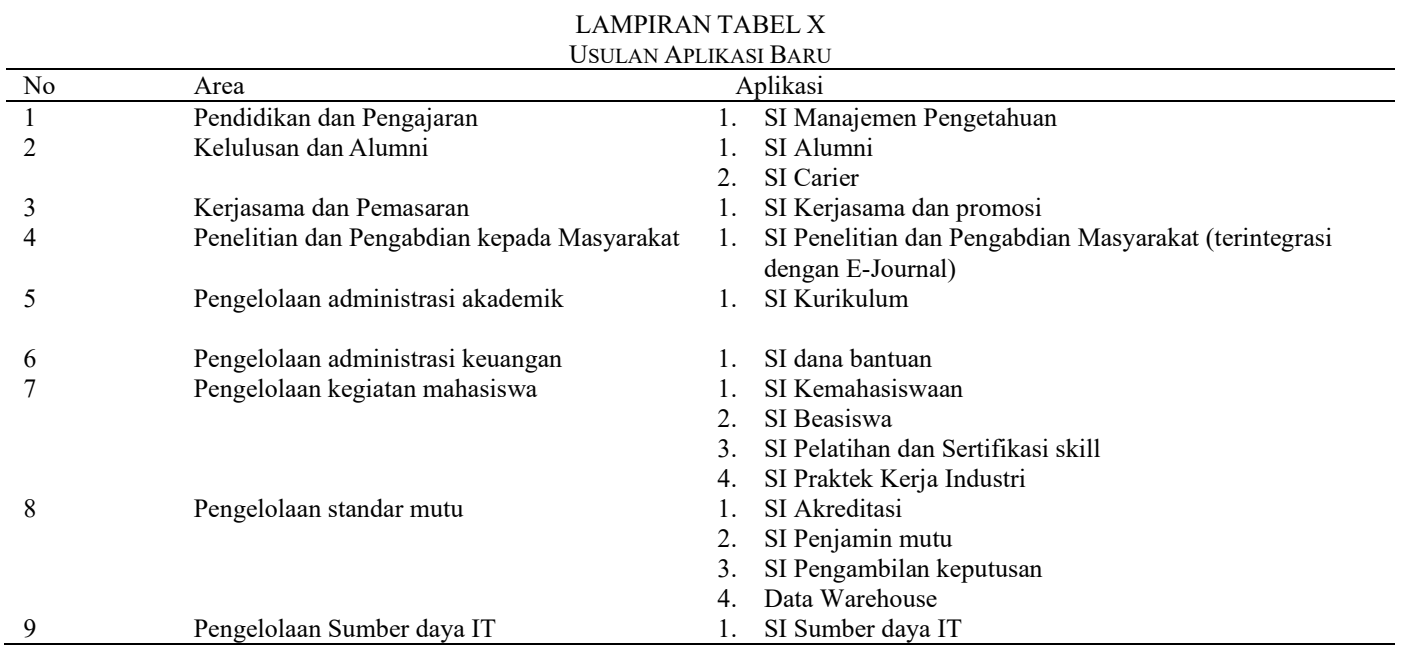

LAMPIRAN TABEL XI

USULAN PENGEMBANGAN APLIKASI LAMA

\begin{tabular}{llll}
\hline No & Area & \multicolumn{2}{l}{ Aplikasi } \\
\hline 1 & Promosi dan Penerimaan Mahasiswa baru & 1. & Pengembangan SI Pendaftaran Mahasiswa Baru online \\
2 & Pendidikan dan Pengajaran & 1. Pengembangan E-Learning \\
3 & Pengelolaan administrasi akademik & 1. Pengembangan SI Layanan (MySTPT) berbasis mobile dan web \\
& & 2. & Integrasi SI Layanan (SMS Center) \\
4 & Pengelolaan administrasi keuangan & 1. Pengembangan SI Keuangan Modul Chasier \\
& & 2. Pengembangan SI Keuangan Modul Ledger \\
5 & Pengelolaan perpustakaan & 1. Upgrade SI Perpustakaan \\
6 & Pengelolaan sumber daya manusia & 1. Pengembangan SI Kepegawaian \\
7 & Pengelolaan sarana dan prasarana & 1. Pengembangan SI Sarana Prasarana Modul Inventory \\
\hline
\end{tabular}


LAMPIRAN TABEL XII ENTITAS BISNIS

\begin{tabular}{|c|c|}
\hline Entitas Bisnis & Proses Kinerja Bisnis \\
\hline 1. Yayasan STP & 1. Yayasan STP Trisakti menetapkan pimpinan STP Trisakti \\
\hline Trisakti & 2. Yayasan menerbitkan aturan pengelolaan STP Trisakti \\
\hline 2. Pimpinan STP & 3. Yayasan Mengontrol kinerja STP Trisakti \\
\hline Trisakti & 4. Pimpinan STP Trisakti melaporkan kinerja dan bertanggungjawab kepada yayasan STP Trisakti \\
\hline 3. Pejabat Struktural & 5. Pimpinan STP Trisakti melalui ketua mengangkat dan mengesahkan pejabat struktural, Tenaga \\
\hline 4. Tenaga Penunjang & Penunjang dan Dosen STP Trisakti \\
\hline 5. Dosen & 6. Pimpinan STP Trisakti membuat aturan dan kebijakan tentang proses kegiatan tridarma perguruan \\
\hline 6. Mahasiswa & tinggi dan pengelolaannya di STP Trisakti \\
\hline 7. Alumni & 7. Mahasiswa, Alumni, Industri, Pemerintah dan Masyarakat merupakan pengguna layanan jasa \\
\hline 8. Industri & pendidikan yang akan dikelola oleh STP Trisakti \\
\hline 9. Pemerintah & 8. STP Trisakti wajib melaporkan dan mengikuti aturan pemerintah dalam hal pengelolaan perguruan \\
\hline 10. Masyarakat & tinggi \\
\hline $\begin{array}{l}\text { 11. Perguruan Tinggi } \\
\text { Mitra }\end{array}$ & 9. STP Trisakti melakukan kerjasama dengan perguruan tinggi mitra STP Trisakti \\
\hline
\end{tabular}

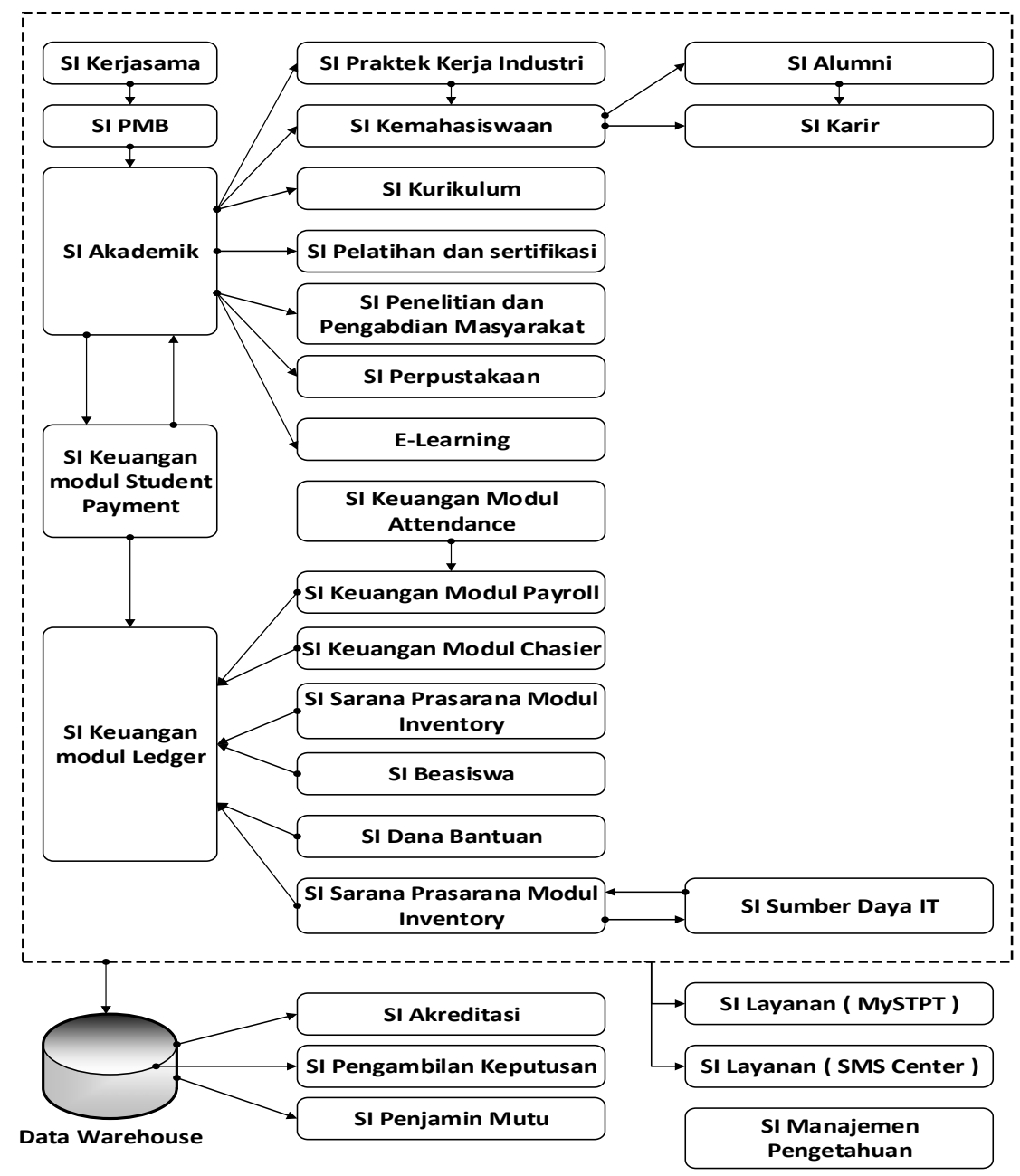

Lampiran Gambar 1. Hubungan Antarsistem STP Trisakti 


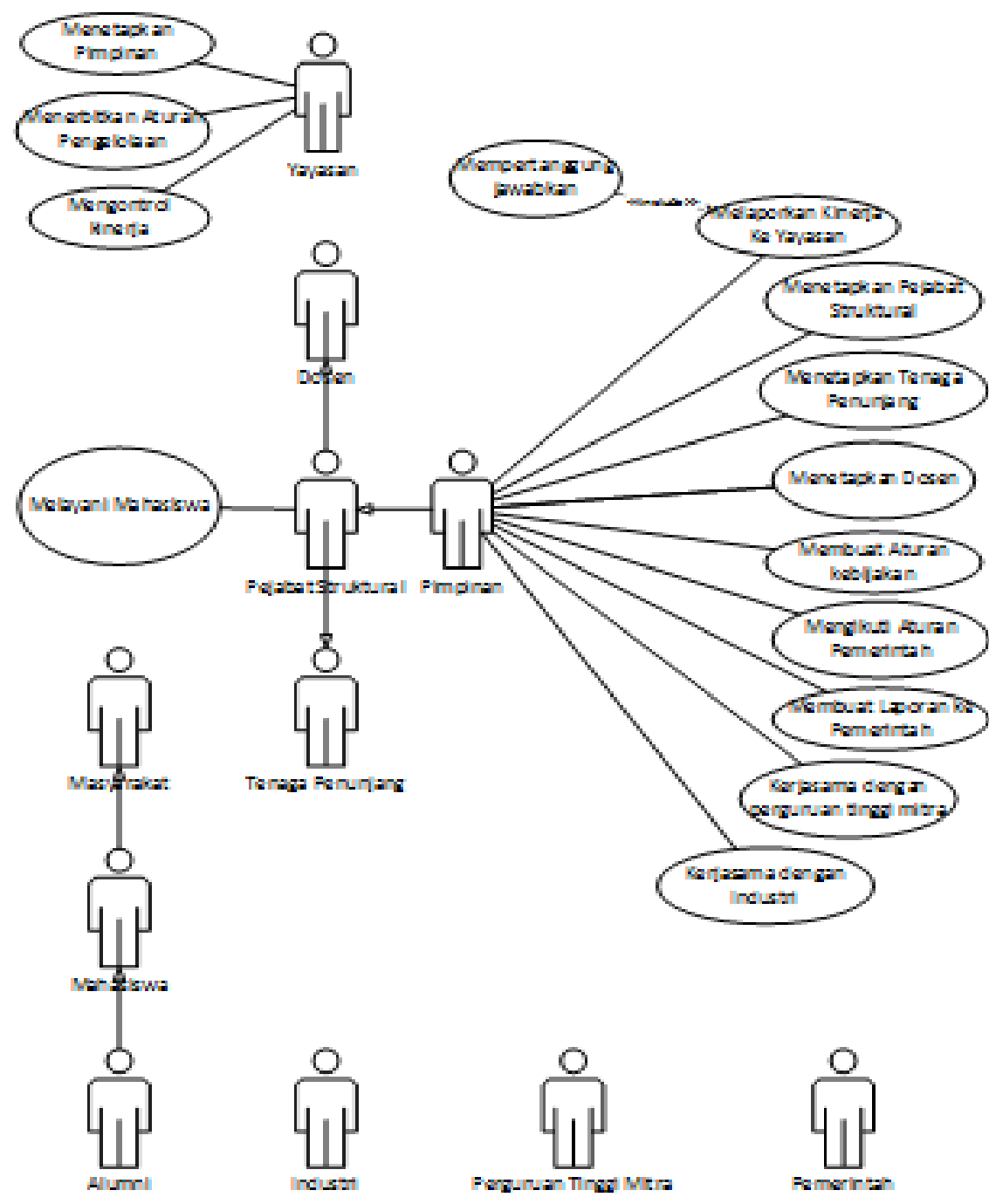

Lampiran Gambar II. Proses bisnis STP Trisakti 


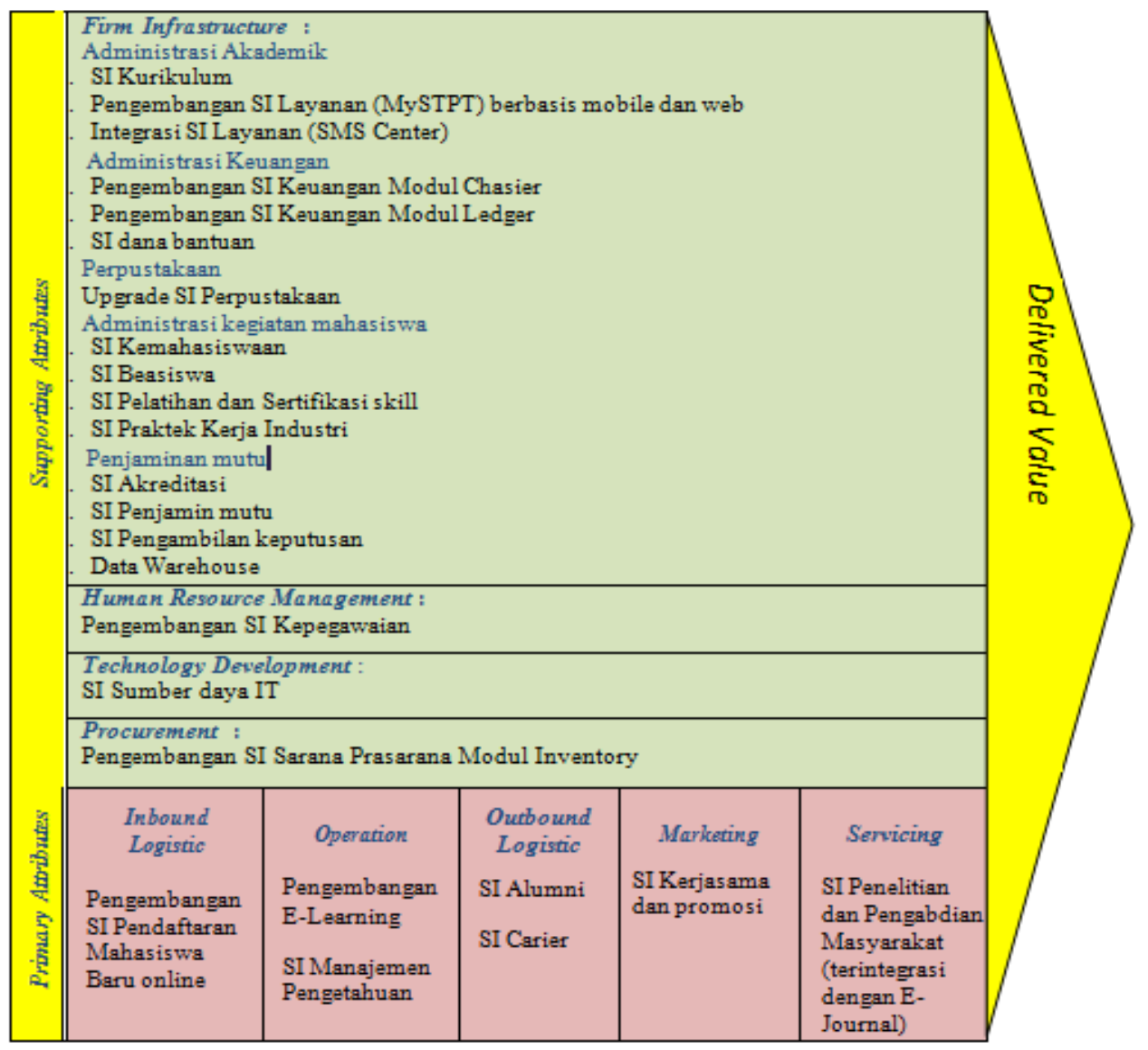

Lampiran Gambar III. Value Chain Strategi Bisnis STP Trisakti

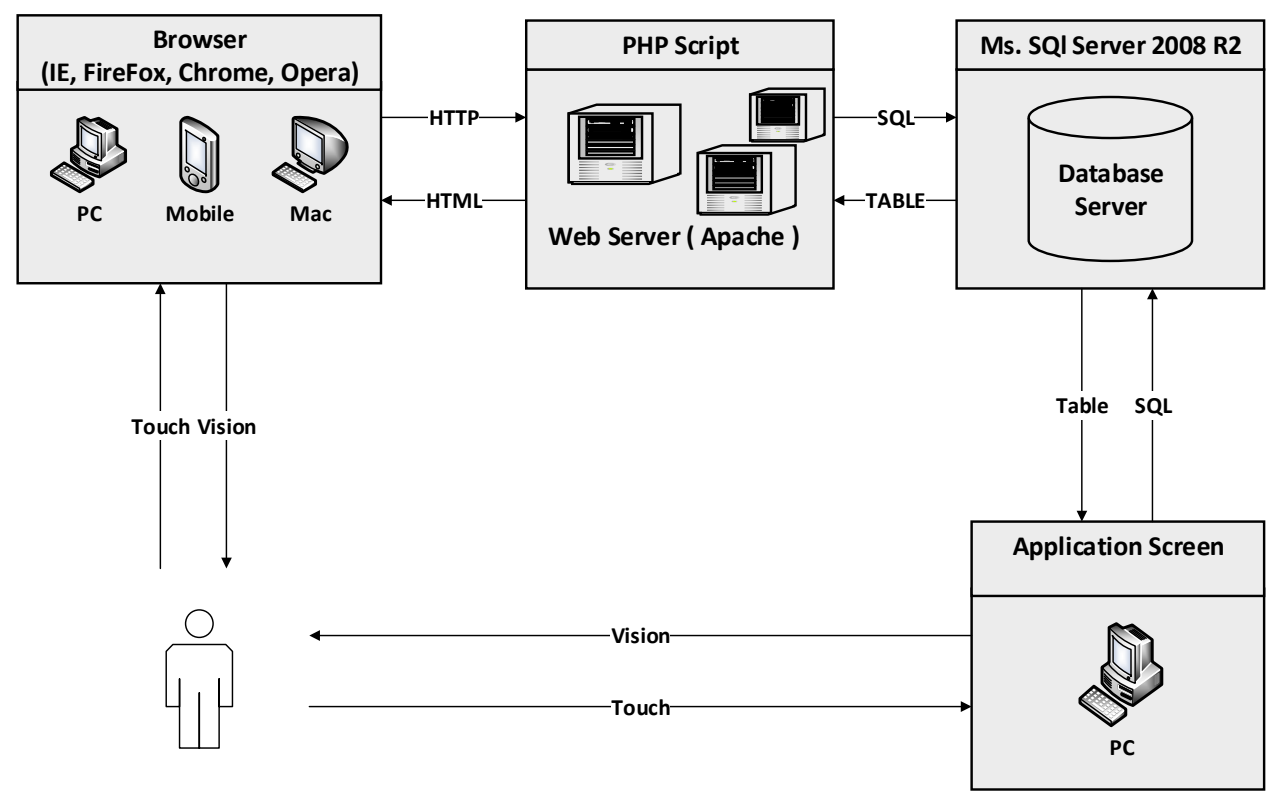

Lampiran Gambar IV. System Design 


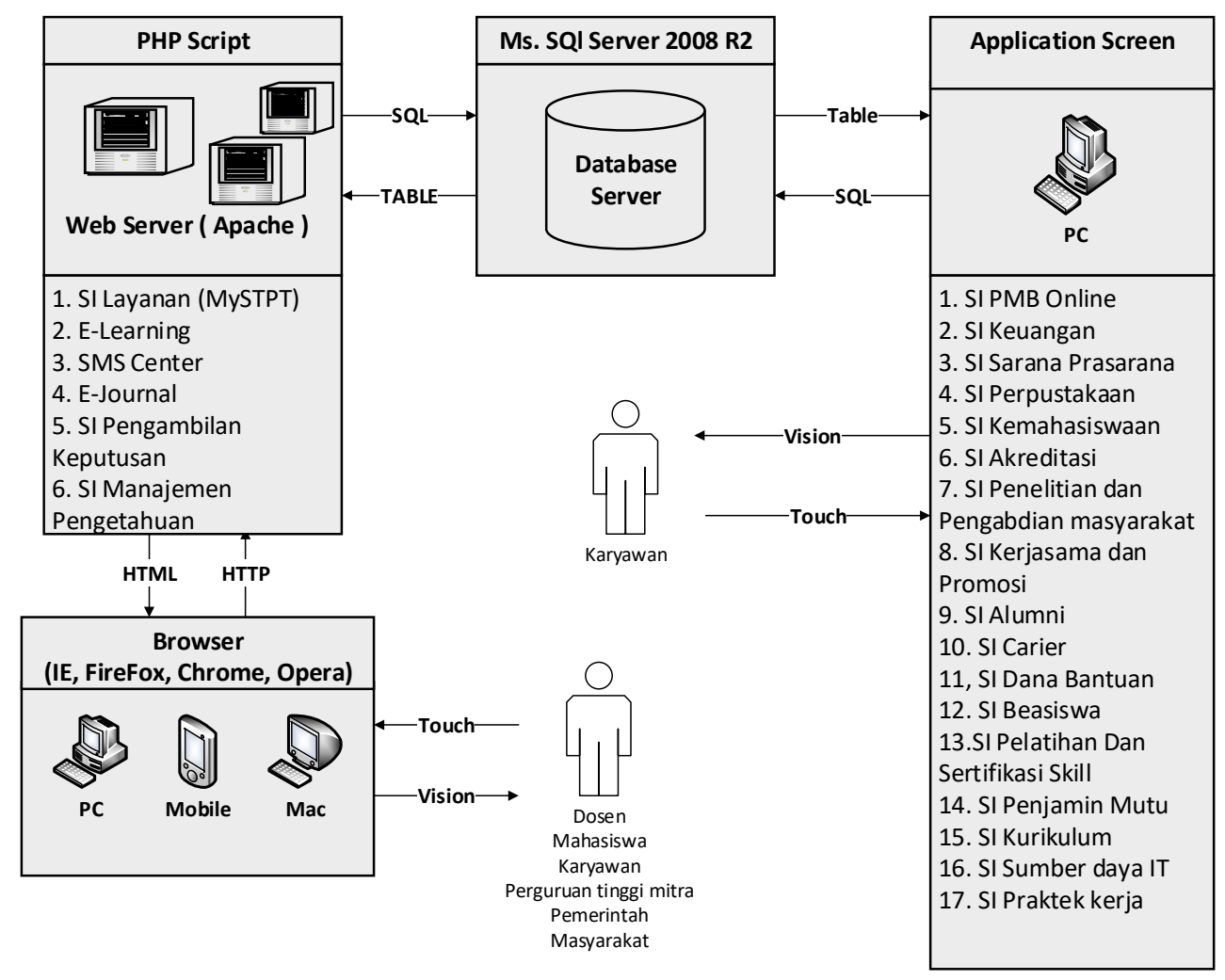

Lampiran Gambar V. Presentation Architecture

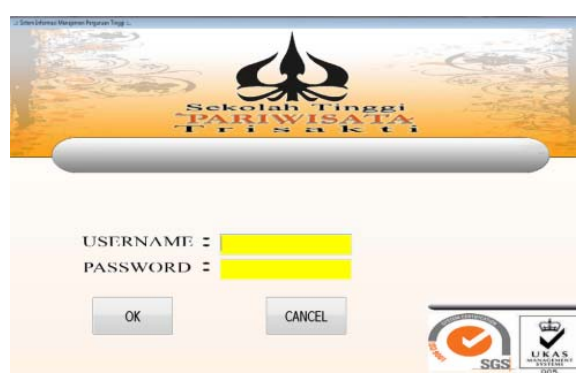

Lampiran Gambar VI. Contoh Form Login

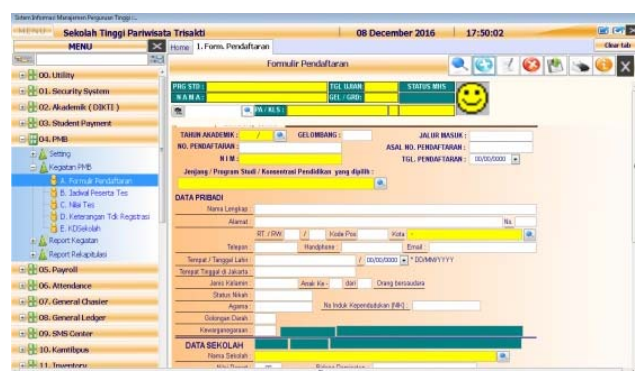

Lampiran Gambar VII. Contoh Form Input dan Menu

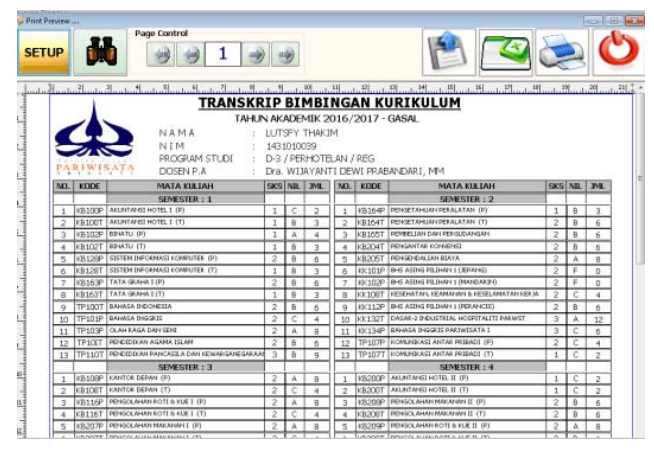

Lampiran Gambar VIII. Contoh Form Output 


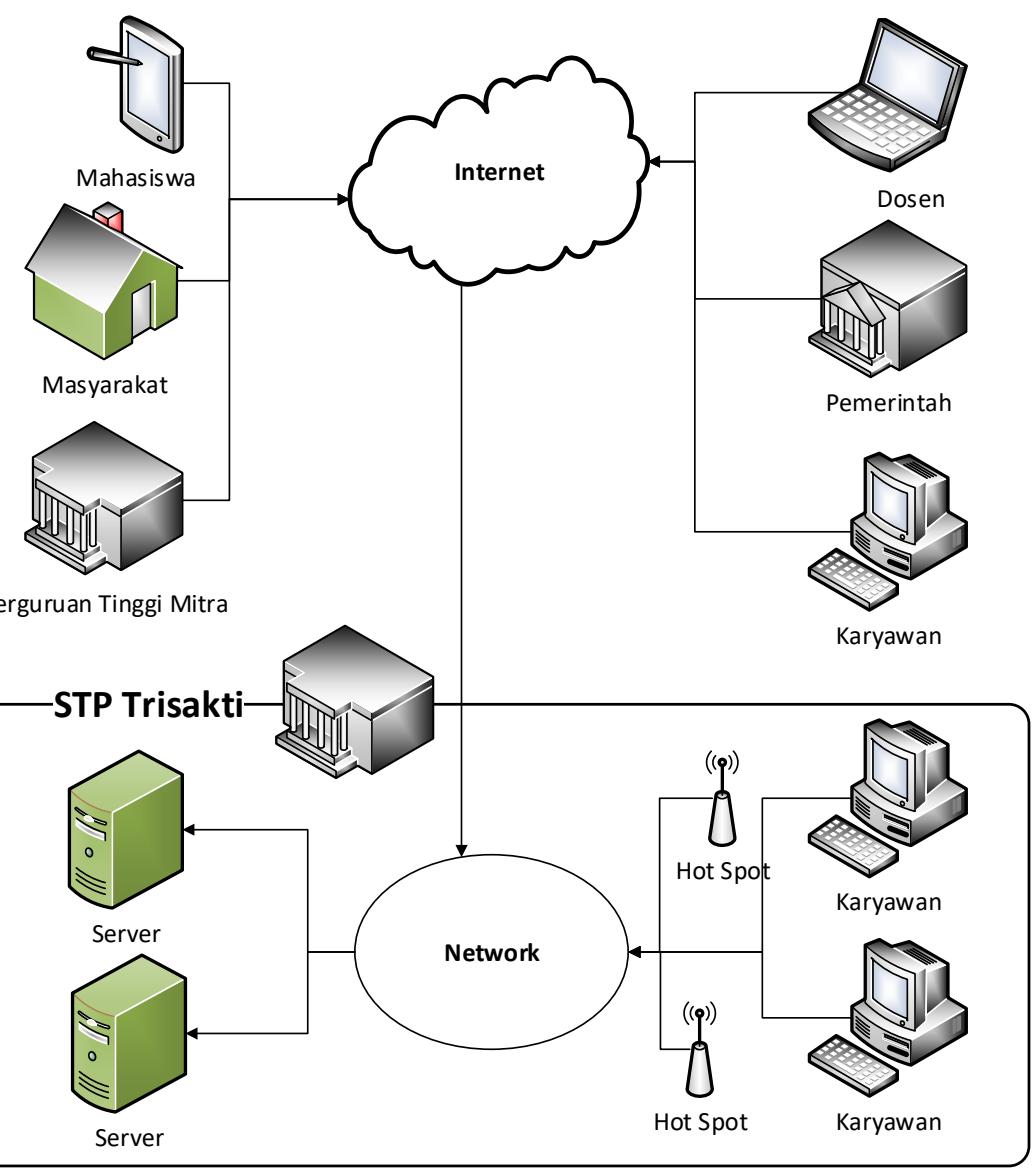

Lampiran Gambar IX. Distributed system Architecture STP Trisakti

LAMPIRAN TABEL XIV

KATEGORi PORTOFOLIO APLiKASI MENDATANG STP TRISAKTI

\begin{tabular}{|c|c|c|c|}
\hline \multicolumn{2}{|l|}{ Strategic } & \multicolumn{2}{|l|}{ High Potential } \\
\hline 1. Pengembangan SI Pendaftaran Mahasiswa Baru online & I & 1. SI dana bantuan & II \\
\hline 2. Pengembangan E-Learning & & 2. SI Sumber daya IT & III \\
\hline $\begin{array}{l}\text { 3. SI Penelitian dan Pengabdian Masyarakat (terintegrasi } \\
\text { dengan E-Journal) }\end{array}$ & $\begin{array}{l}\text { I } \\
\text { II }\end{array}$ & 3. SI Manajemen Pengetahuan & II \\
\hline 4. SI Carier & & & \\
\hline 5. Data Warehouse & & & \\
\hline 6. SI Pengambilan keputusan & $\begin{array}{l}\text { I } \\
\text { I } \\
\text { II }\end{array}$ & & \\
\hline 1. Pengembangan SI Keuangan Modul Chasier & I & 1. Pengembangan SI Sarana Prasarana Modul & I \\
\hline 2. Pengembangan SI Keuangan Modul Ledger & & Inventory & \\
\hline $\begin{array}{l}\text { 3. Pengembangan SI Layanan (MySTPT) berbasis mobile dan } \\
\text { web }\end{array}$ & I & $\begin{array}{l}\text { 2. Upgrade SI Perpustakaan } \\
\text { 3. Integrasi SI Layanan (SMS Center) }\end{array}$ & $\begin{array}{l}\text { I } \\
\text { II }\end{array}$ \\
\hline 4. SI Penjamin mutu & III & 4. SI Kemahasiswaan & IV \\
\hline 5. SI Praktek Kerja Industri & & 5. SI Akreditasi & IV \\
\hline & II & 6. SI Kerjasama dan promosi & IV \\
\hline & II & 7. SI Alumni & $\mathrm{V}$ \\
\hline & & 8. SI Beasiswa & $\mathrm{V}$ \\
\hline & & 9. SI Pelatihan dan Sertifikasi skill & III \\
\hline & & 10. SI Kurikulum & $\mathrm{V}$ \\
\hline Key Operation & $\mathbf{P}$ & Support & $\mathbf{P}$ \\
\hline
\end{tabular}

Keterangan : P adalah Periode perencanaan implementasi Sistem Informasi 
LAMPIRAN TABEL XV JADWAL PERENCANAAN PENGEMBANG Si/Ti STP TRISAKTI

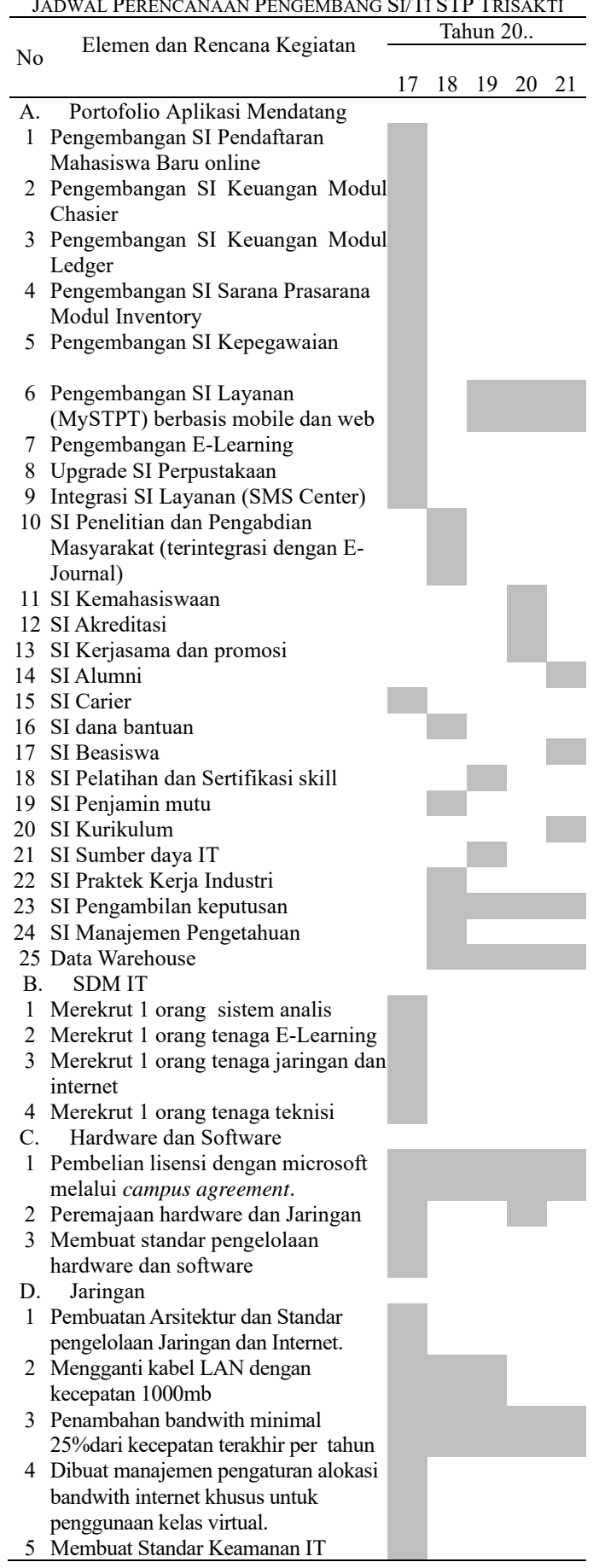

LAMPIRAN TABEL XVI EVENT PERENCANAAN PROYEK

\begin{tabular}{|c|c|c|c|}
\hline \multirow{2}{*}{\multicolumn{2}{|c|}{ NoEvent }} & \multicolumn{2}{|c|}{$\begin{array}{l}\text { Januari } \\
2017\end{array}$} \\
\hline & & & 34 \\
\hline 1 & $\begin{array}{l}\text { Pembelian lisensi dengan microsoft } \\
\text { melalui campus agreement secara berkala } \\
\text { dan berlanjut. }\end{array}$ & $\mathrm{x}$ & \\
\hline 2 & $\begin{array}{l}\text { Perancangan anggaran untuk peremajaan } \\
\text { hardware per } 3 \text { tahun sekali }\end{array}$ & $\mathrm{x}$ & \\
\hline 3 & $\begin{array}{l}\text { Membuka lowongan kerja sebagai sistem } \\
\text { analis, jaringan dan internet, e-learning dan } \\
\text { teknisi masing-masing } 1 \text { orang }\end{array}$ & $\mathrm{x}$ & $x \quad x$ \\
\hline 4 & $\begin{array}{l}\text { Perancangan standar pengelolaan Jaringan } \\
\text { dan Internet }\end{array}$ & & $\mathrm{x}$ \\
\hline 5 & Perancangan standar keamanan IT & & $x$ \\
\hline$\underline{6}$ & Perancangan standar hardware dan software & & $x$ \\
\hline
\end{tabular}

LAMPIRAN TABEL XVII STANDAR WAKTU PEMBUATAN APLIKASI

\begin{tabular}{lll}
\hline No & Event & Waktu ( Minggu ) \\
\hline 1 & Pembuatan Database & 2 \\
2 & Desain antar muka aplikasi & 3 \\
3 & Pembuatan kode program & 8 \\
4 & Pengujian aplikasi & 1 \\
5 & Dokumentasi dan Pelatihan & 1 \\
\hline
\end{tabular}

LAMPIRAN TABEL XVIII JADWAL RENCANA KEGIATAN 5 TAHUN

\begin{tabular}{|c|c|c|c|}
\hline \multicolumn{2}{|c|}{ NoRencana Kegiatan } & \multicolumn{2}{|c|}{$\begin{array}{l}\text { Tahun } 20 . . \\
1718192021\end{array}$} \\
\hline & $\begin{array}{l}\text { Penyelesaian pengembangan aplikasi } \\
\text { yang sudah ada sebelumnya }\end{array}$ & $\mathrm{x}$ & \\
\hline 2 & Perekrutan SDM IT & $\mathrm{x}$ & \\
\hline 3 & $\begin{array}{l}\text { Pembelian hardware, software dan } \\
\text { infrastruktur jaringan }\end{array}$ & $\mathrm{x}$ & \\
\hline 4 & $\begin{array}{l}\text { Pembuatan Aplikasi yang diusulkan } \\
\text { yang termasuk dalam kategori key } \\
\text { operation dan strategic }\end{array}$ & $\mathrm{x}$ & \\
\hline 5 & $\begin{array}{l}\text { Pembuatan Aplikasi yang diusulkan } \\
\text { yang termasuk dalam kategori key } \\
\text { operation dan High potential }\end{array}$ & & \\
\hline 6 & $\begin{array}{l}\text { Pembuatan Aplikasi yang diusulkan } \\
\text { yang termasuk dalam kategori key } \\
\text { operation dan Support }\end{array}$ & & $\mathrm{x}$ \\
\hline 7 & $\begin{array}{l}\text { Pembuatan Aplikasi yang diusulkan } \\
\text { yang termasuk dalam kategori support }\end{array}$ & & $\mathrm{x}$ \\
\hline
\end{tabular}

